Article

\title{
The Demonization of Islam through Social Media: A Case Study of \#Stopislam in Instagram
}

\author{
Sabina Civila ${ }^{1}\left(\mathbb{D}\right.$, Luis M. Romero-Rodríguez ${ }^{2,3, *}$ and Amparo Civila 4 \\ 1 Department of Education Sciences, University of Huelva, 21004 Huelva, Spain; sabicivila@gmail.com \\ 2 Department of Communication Sciences, Rey Juan Carlos University, 28942 Madrid, Spain \\ 3 ESAI Business School, Espiritu Santo University, Guayaquil 092301, Ecuador \\ 4 Department of Education Theory and History, University of Malaga, 29010 Malaga, Spain; acs@uma.es \\ * Correspondence: luis.romero@urjc.es
}

Received: 22 September 2020; Accepted: 24 November 2020; Published: 1 December 2020

\begin{abstract}
This article studies the process of demonization, its consequences, and how social media contribute to the formalization of its axiology. The demonization of societies aims to create social subjects that fit into the idea of the "other" by exposing them to compulsory invisibility. This research's main objective was to examine how demonization is used as a weapon of oppression to devalue specific individuals through the hashtag \#StopIslam and Instagram's role in this process. The methodology used for this purpose has consisted of an empirical and quantitative analysis of the most recent (1 January 2020-31 July 2020) posts on Instagram with \#StopIslam, analyzing the images and the content. The study has determined how, through social media manipulation, erroneous ideas are transmitted that prevent the Islamic collective's integration, especially in European countries. The conclusions will reflect hate speech and how the Islamic world's demonization results in the Muslim community's stigmatization, racism, and Islamophobia. Although there are different articles related to demonization and hate speech, there are not many scientific resources that explain these variables on Instagram and how it affects the inclusion of the Muslim community in Europe, significantly when the time spent on the Internet is growing.
\end{abstract}

Keywords: Instagram; demonization; hate speech; arab world; Islamophobia; social media

\section{Introduction}

Throughout history, from the social discursive podium and the establishment, it has been possible to demonize and devalue social groups that are perceptively located in a subordinate place, thus creating a negative image of the other. Social domination results from an unequal division of power, where those who have less power are forced to see their life expectancies limited [1]. This limitation is expressed in various ways, usually from demonization, through polarization, exclusion to invisibility. Although in some research, demonization is treated as a rhetorical figure (e.g., [2]), this study will delve into its media construct and more immediate consequences.

The Muslims' demonization is carried out fundamentally by relating, by conceptual simplification, Muslims to terrorism. By constructing the suspected subject as a 'potentially terrorist Muslim', society can misinterpret this group's nature and generate a community feeling that damages the social perception of people who practice Islam [3]. In this way, all Arabs may be identified as radical Muslims and terrorists, offering a mistaken and widespread image of Arab countries that, out of ignorance, causes other societies to turn away from it out of fear [4], which eventually results in the stigmatization of the Muslim community, racism, and Islamophobia.

The social media, as massifiers of the constructs of reality, play an essential role in introducing demonization into society and in promoting all its consequences, since they use instruments such as 
repetition of expressions, symbolic polarization, and euphemisms, among other resources, which distort the vision of those who receive these messages by making a conceptual simplification, fundamental for the understanding of public opinion [5]. Moreover, information is exaggerated by making comments without substantiating what is expressed, manipulating the reader's opinion about a news event. According to Cleland (2014) [6], social media sites have the right characteristic to spread racist opinion and hate speech.

For this reason, and in order to understand how demonization is used as a weapon of oppression in the case of \#StopIslam and the role of Instagram in this process, a mixed methodology is used, qualitative techniques to explore the hashtag based on the "five walls of Islamophobic hate" and a review of the literature using the Web of Science (WoS) and Scopus, under the search criteria-and their Boolean algorithms_-" demonization", "social media" and "Islam", terms which are included in both Spanish and English and quantitative techniques using SPSS to evaluate the dates. This led to a review of the grounded theory with which the same epistemological, ontological, and theoretical forms would be correlated.

\section{Social Media, Demonization, and Islam}

\subsection{Social Media}

With the widespread use of the Internet, the way by which the population interacts has been modified [7]. Communication begins to be more interactive. Users can generate social media content by becoming prosumers and modifying the usual communication scheme [8]. Since the mid-2000s, social media turned into fashion and a place where everybody wants to be; platforms as Facebook, Twitter, Youtube, and Instagram generate content and keep people in it for many hours. The term "social media" makes one think whether not all media are social in some way. This depends on how social media is understood [9]. In the present study, social media is going to be understood, according to Fuchs [10], under community and communication criteria. Social media is considered a social structure composed of a set of users related to some criteria. Moreover, it allows generating new business opportunities, revolutionizing social development, and consolidating existing relationships in the offline world to build new links [11].

There is a long list of social media (Facebook, Twitter, Youtube, Linkedin, etc.). However, Instagram, according to Statista (2020) [12], is the social network with the highest increase in users during the quarantine caused by the Covid-19 pandemic, created in 2010 by Kevin Systrom and Mike Krieger, and aimed at photography enthusiasts, but, over time, it has grown and added functionality. Furthermore, a study realized by Hootsuite and We Are Social in 2019 [13] provided evidence that Instagram has been the fastest growing social network since its birth.

On Instagram, it is also possible to observe social networks' adverse effects, as in traditional media $[14,15]$. Generally, in this network, they have been attributed to the process of social comparison, which can cause demonization of a society that is reflected as inferior [16].

\subsection{Demonization: Concept and Characteristics}

Demonization consists of the process through which the source is sacralized with dialectical and discursive resources such as discretion, integrity, or goodwill, promoting a symbolic construction of reality created under the conceptual simplification protagonist-antagonist, which causes the "other" to be not culturally accepted, inferior or inconsiderate, carrying with it discrimination, paradigms of hatred and stereotypes, and clichés, which, therefore, devalue it morally and perceptively, damaging their social identity and even their identity self-recognition [17]. Online antagonism over social media accelerates racism through the dispersal of harmful discourse [18].

Demonization leads to an attitude of distrust in public opinion, which removes moral restrictions, intending to turn the other into a morally inferior being, criminalizing his views, radicalizing the discourse, and distracting and polarizing society at the same time that the ideas of the sender are 
exposed as correct and justified [5]. Issues such as radical patriotism, racism, terrorism, opposition, or ethnic minorities carry with them a burden of demonization towards the subject with contrary convictions [19].

Quoting Field (1996) [20], alluding to the cinematographic narrative paradigm, in order to generate identification with the protagonist, and therefore the express or tacit rejection of the antagonist, it is necessary to create a dynamic of confrontation, even if it does not exist, using the resources of empathy and transference. Thus, the discursive process of demonization would be composed as follows [5]: (1) To explore the interests of the audience, which allows to deepen them and to achieve empathy through the speech; (2) Confront the interests of the group to be demonized, building points of disagreement between the target audience and the group to be demonized; (3) Standing up for the interests of the public, the demonized group is accused of going against the common or at least majority interest; (4) Introduce disqualifying sound bites to the speech, such adjectives should be short, few, forceful, and easy to memorize; (5) Reiterate the adjectives frequently in the speech. Repetition is the key to persuasion and the institutionalization of realities; and (6) Radicalizing attacks to the point of stigmatizing the opposite.

At this point, reference could be made to Goffman's concept of "impaired identity" (1963) [17] concerning stigmata. The author [17] makes an extensive journey through all the typologies of stigmas and concretely puts his attention on the norms, referring to how the individual observes the other through the meanings that society constructs; this is produced by what Goffman (1963) [17] qualifies as "symbols of stigma" (p. 63), closely linked to the devaluation of the individual by society, which consumes information, constructs a socialized reality, and stigmatizes from those common signs.

These stigmas divide between an "us" (the so-called integrated or normal) and a "them" (the deviant, the marginal, the "others"), which is determined not only by socio-economic conditions, but also by the reading that is made of them, and the interpretation that they make of "themselves" and about "us" [3]. With this concept, Goffman (1963) [17] wants to account for the disabled individual's situation to obtain full social acceptance. These stigmas encourage the discrediting of the individual. In this regard, the demonization takes advantage of these stigmas to promote the use of disqualifiers and radicalize the stigmatized attacks, so it is simpler to dissociate the "other" of an equitable moral nature to the "we", reifying it and making it object of hate through the speech, as it happened with the exercise of the two minutes of hatred to Emmanuel Goldstein, to which the workers of Eurasia were exposed in the Orwellian dystopian 1984.

Some authors, such as Santos (2017) [1], put forward the idea that demonization and social inequalities and hierarchies between different countries would be eliminated during globalization. However, on the contrary, the opening of cultural and economic borders tends to reinforce this type of behavior. As a result, acts of "xenophobic deglobalization" are emerging, such as Brexit, Catalan separatism in Spain, and many of the United States' protectionist policies.

\subsection{Demonization and Its Consequences in Social Media}

As has been understood so far, the process of demonization provides an opportunity to create misguided knowledge about people who are ethnically and culturally distant. This is how racism is conceived, which in general terms is a broad form of discrimination that encompasses social, cultural, and intellectual aspects to nullify the diversity and heterogeneity of a society, community, or ethnic group [4], Islamophobia, which is a manifestation of dislike towards people who profess Islam or come from countries where it is professed [21], and finally, the invisibility that encourages the creation of deteriorated and oppressed identities [22]. Social media contribute to freedom of speech, allowing people to express their thinking and share their feelings. However, some people abuse this and send offensive comments that could negatively affect the people [23]. The most damaging impact of freedom of speech is the number of messages full of hate shared by unconscious people. According to Putri et al., (2020) [23], hate speech "is any kind of communication which is offensive, underestimating, 
and humiliating an individual or group of people" (p. 1). As can be observed, the consequences of demonization and hate speech in social media cause: Racism, Islamophobia, and invisibility.

\subsubsection{Racism}

According to some theorists such as Baum (2006) [24] and Banton and Harwood (1975) [25], the concept of racism began to develop theoretically in the 1930s, associating itself with state doctrines based on racial superiority. It emerged mainly in the German socialist period between 1933 and 1945 .

Although the term was developed at the time mentioned above, it does not mean that there were no earlier racist moral, institutional, and practical principles. Previously, this concept was known as "race relations" [26], for example, with the racial segregation of the United States that began institutionally in 1790, the apartheid in South Africa (1948-1992) or, with historical examples as in ancient Rome, when an alien did not have status civitatis.

To develop the concept of racism, it is essential, first, to understand two other concepts: "racialization" and "racialism". Two meanings can be distinguished for the term "racialization". Firstly, it will be equated with the imbalance between racial groups considering races and the different hierarchies [26]. On the other hand, there are no racial groups in its second understanding, but races are ontologically empty social constructs. It is recognized that the processes of race production are relational. For one racial group to exist, another must be produced, since it does not exist as a single whole.

For its part, "racialism" consists, according to Moore (1984) [27], in the dislike, rejection, and inferiorizing that some members of a racial group feel with another group. This concept involves perceiving human beings as distinguishable according to racial categories. Once these concepts are understood and differentiated, it can be said that racism is not only a way of giving meaning to sociodiversity, as racialism does, but also of positioning them in order. Racism implies a categorization based on the assumption of races' existence, introducing the idea of inequality between them. According to Campos (2012, p. 10) [26]:

Any racialization process does not necessarily lead to the implementation of racist logic or practices, and every racialism does not necessarily result in a hierarchy of categories. At the same time, racism should not be perceived as an inevitable consequence of racialization or racialism. Racism is only a very particular derivation produced by the inclusion of an arbitrary principle of hierarchies in a previously defined distinction between human groups.

Racism, for Fanón (2010) [28], is a global hierarchy of superiority and inferiority that has been politically supported and reproduced as a structure of domination for many centuries by the "Western-centric" system [29]. The people at the top of the pyramid are socially recognized as human beings with access to their rights, while those at the bottom find their humanity and rights questioned [28].

For its part, more recent research refers to two types of racism: ancient racism and modern racism, since, like any social construction, as societies have advanced, the concept and its use has changed [30]. According to McConahay (1986) [31], ancient racism involves a series of aggressive stereotypes about intelligence, workability, and acceptance of open discrimination, while modern racism is more subtle and indirect, as well as accepted by society [30]. According to Taguieff (1991) [32], the core elements of racism considered to be ancient are: (1) the biological doctrine, which consists of the biologization of social categories, identities, and collective differences, and (2) inequality among persons, which implies the superiority of some races and the dependence of others.

Sear and Kinder (1970) [33] began to discuss modern racism when it was thought that racism was disappearing, although nothing could be further from the truth. Racism was being 'modified' to fit the new values, orders, and dynamics of modern society. In 1972, 95\% of Americans thought that their intelligence was the same as that of African Americans, claiming that there was no difference between them and that, therefore, they were not racist despite questioning this thought [34]. According to 
Taguieff (1991) [32], there are two mutations in the new racism: the shift from race to culture and the shift from inequality to difference. Pettigrew (1989) [34] explain that the attitudes of modern racism are not exclusively American $[35,36]$, but they also compete with modern racism in Europe. The characteristics of this modern racism are:

- They appear to be against discrimination, although, in practice, they resist initiatives to correct it.

- Feelings of fear and threat based on the group, considering that the State better treats minorities.

- Blaming the victim who is at a low social level, thus denying the existence of racism-for example, denying the scarcity of opportunities and over-exalting the scarcity of efforts. This point leads to two specific types of behavior: the acceptance of new norms without complete internalization and the emergence of "indirect micro-aggressions" and avoidance.

\subsubsection{Islamophobia}

As a consequence of the racism towards people who profess Islam, the term "Islamophobia" is beginning to be used, which, according to Bourekba (2018) [21], is a phenomenon distinguished by displays of hatred and hostility practicing acts of discrimination, violence, or exclusion towards people or institutions based on their belonging to and professing Islam.

The term "Islamophobia" is making its way into Western societies without an agreed definition [37]. In fact, during the last years, the term islamophobia has been discussed, although it has existed as a linguistic construct for about 100 years [38], appearing in literary works of the beginning of the 20th century where the French colonies are mentioned, and the Muslims are placed as the main enemies of Christianity and the Europeans [39]. However, its use has been consolidated, especially after the terrorist attacks of 2001 in New York [37].

It was not until 2004 that the Council of Europe [40] in the conference of Islamophobia and its consequences on young people advanced a definition of Islamophobia as "fear or prejudice towards Islam, Muslims, and everything related to them. Whether it takes the form of daily manifestations of racism and discrimination or other more violent forms, Islamophobia constitutes a violation of human rights and a threat to social cohesion".

This situation, beyond the social attitude itself against people who profess the Muslim religion and culture, generates "the image of the enemy", i.e., a belief of certain groups that their security and values are threatened by another group, leading to the possibility of violence and destruction [41].

In the social sciences, we find concrete manifestations of Islamophobia, for example, in the works of Karl Marx and Max Weber, as Sukidi suggests (2006) [42]. These manifestations of Marx and Weber show that Muslims are fatalistic and irrational people, so no severe knowledge can come from them [42]. Weber and Marx's views produce an epistemic Islamophobia in which Muslims are incapable of producing science, even though historical evidence has shown the influence of scientific advances in the Arab world on modern science and Western philosophy [43,44]. According to Conway (1997) [45], the attitudes that encourage Islamophobia are: (1) The interpretation of Islam as a monolithic, static, anti-change block; (2) The consideration of Islam as inferior to Western culture and religion; and (3) The view that all Islam is violent, aggressive, and supports terrorism.

According to Bourekba (2018) [21], by 1990, 10\% of Spaniards rejected Muslims, based on information from the European Values Study (1990). In 2006, this proportion increased to 64\% [46]. Currently, an increase of 467.35\% in Islamophobia has been certified between 2014 and 106.12\% between 2015 and 2016 [47] (Figure 1).

According to Geisser (2003) [48], in La Nouvelle Islamophobie, there are two types of islamophobia. The first is that which is rooted in the colonial context and significantly linked to institutional treatment. The second is a "new Islamophobia", which consists of both historical and contemporary components that result in a racist discourse towards Islam.

Within Islamophobia, we can find another term, the "anti-Muslimism" [48], which is an Islamophobia applied beyond the outside since it positions itself against an 'enemy' that is also internal. This occurs in countries where a minority Muslim population is increasing due to migration (e.g., Belgium, Spain, 
Denmark, France, or Sweden). According to Vakil (2009) [49], the term Islamophobia is accepted by the international community. However, in the U.K., it has been debated on multiple occasions, generating minor and vital questions about the term, which are outside the scope of this document, but it is crucial to a better understanding specified the differences. This means that, according to the author above, "Islamophobia" would be fear of Islam as a possible external threat to our culture, while "anti-Muslimism" is the rejection of Islam in our territory.

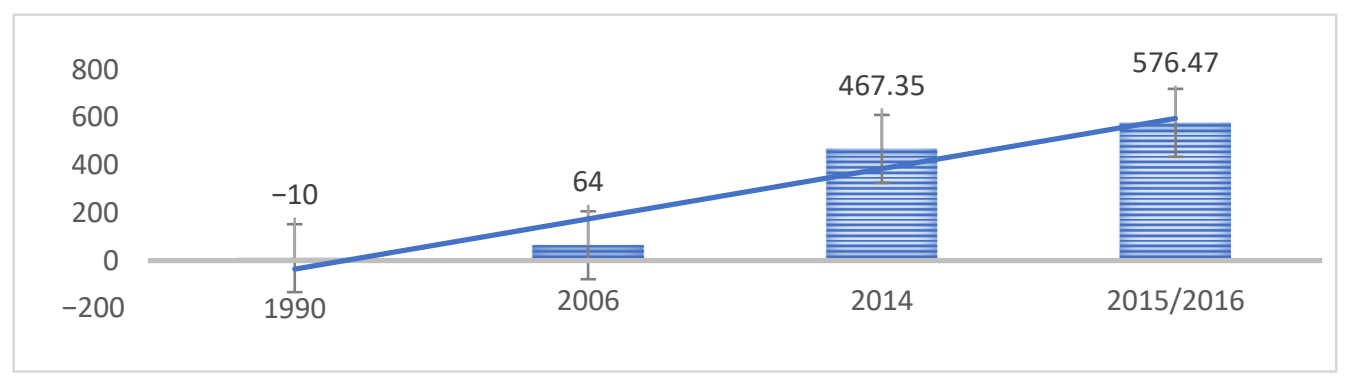

Figure 1. Evolution of the rejection of Muslims in Spain. Source: Own elaboration from Bourekba (2018, p. 19) [21].

Following the attack of 11 September 2001, an international offensive known as the 'war on terror' was launched, which was pointed out by many authors as the new beginning of the institutionalization of Islamophobia [38,50]. According to Poole et al., (2020) [51], in 2016, when the Belgium attacks were perpetrated, this was reinforced and gave rise to the hashtag \#StopIslam.

In the specific case of Spain, the Agreement to strengthen unity in defense of freedoms and the fight against terrorism (cuerdo para afianzar la unidadendefensa de las libertades y en la lucha contra el terrorismo), officially known as the 'anti-jihadist pact', was publicly announced on 2 February 2015. This pact demonstrates how legislation is drafted and applied according to different logics. In a silent way, and justified by the security tools, an institutional Islamophobia based on standardized and legally legitimized suspicion has been established. A suspicion that extends to the entirety of a diverse group of people conceived as a unitary collective because of its "potential propensity for radicalization" [1] (p. 26), with radicalization being understood in this context as "the path of a Muslim person who gradually becomes fanatical, who perceives the world only based on his or her exclusive faith and who ends up being a supporter of armed or terrorist action" (p. 21) [52].

Violent radicalization is assumed to be one of the main risks to national security. However, in the process of social generalization and discursive minimization, Muslims are constructed, even by acts of government, as the new enemy of democracies by the political authorities in power (p. 24) [52].

Some facts carried out by the powers-that-be to prevent this violent radicalization (for example, closing down Muslim cemeteries and banning the wearing of the veil) show how Islamic religiosity's invisibility is promoted in public space. Thus, the Muslim citizen who does not hide his religious tendency in the public space will arouse more considerable suspicion and try to acculturate and 'domesticate'. These attempts at domestication can be considered forms of institutional Islamophobia. Other cases of instrumental Islamophobia include pre-trial detentions that cannot prove crimes and how such procedures are carried out [1].

This concept of institutional Islamophobia for Said (1990) [53] is nothing more than a reproduction of the fanaticism with which, from a western conception, Muslim Arabs representing the local imaginary have been constructed when the condition of Muslims is evoked.

Islamophobia has also become more prominent on social media [54] through tools such as hate speech, disinformation, and fake news [55], along with Islamophobia' myths' that Islam is again the modern values [56]. Islamophobia on social media is defined by Vidgen and Yasseri (2020) [57] as "content which explicitly expresses negativity against Muslims" (p. 69). Islamophobic discourse online has also increased due to the online world's characteristics like viral, comments, and share [50]. We can 
observe some hashtag against Islam in social media such as \#StopIslam, \#StopislamizationofEurope, \#IslamTerrorist.

As a result of Islamophobia, we find social exclusion, which is the process that prevents the satisfaction of people's basic needs and their participation in society, as well as the lack of protection of their fundamental rights, so they are exposed to inequality, discrimination, and non-freedom of religion or expression, increasing the likelihood of disorder, which causes a social imbalance [58]. As a form of protecting people who are stigmatized in social media, companies such as Unilever, Honda, and Coca-Cola have removed their advertising from social media (Facebook) from 1 July 2020, with the hashtag \#StopHateforProfit. The main aim is to handle hate speech and misinformation.

\subsubsection{Invisibility}

According to Bastidas and Torrealba (2014) [22], invisibility is defined as the cultural processes carried out by a hegemonic group to suppress a minority group's will to oppress its identity and limit resistance to domination, as well as to maintain socio-cultural control over it. In the same spirit, Fernández Ortiz (1987) [58] explains that invisibility is intended to undermine underdeveloped countries' cultures, since they cannot compete with the most powerful civilizations' cultural industries.

The term "invisibility" refers to a social group that has been neglected and discriminated against by the power elites. Invisibility is related to discrimination against minorities and social vulnerability. As we have seen ut supra, discrimination against minorities stems from the way reality is constructed, since there is a "we" and "others" in it, and when the "others threaten the hegemonic group", they respond by closing in on themselves and excluding the different one [37]. On the other hand, social vulnerability is seen as the suppression of people's rights. In this sense, invisibility is linked to the following theoretical models, according to Bastidas and Torrealba (2014) [22]:

- Marxism: especially with the concept of alienation through which human beings feel isolated or alienated from the nature to which they belong and even dominated. Invisibility is linked to this theory when people belonging to a minority group accept discrimination as something natural.

- Critical theory of the Frankfurt school: it is established that through critical analysis, the human being can free himself from oppression. According to critical theorists, every human being has a creative potential that helps him to overcome. The relationship with the concept of invisibility is that the affected person can become aware of it and cover it through the actions, turning it into a process of visibility.

- Symbolic interactionism: this theory is based on understanding the ability to think as a change process, resulting from the interaction between the person and the social environment [37]. Within this theory, it is accepted the approach of Erving Goffman (1970) [17] on the identity of the ' $I$ ', which holds that one acts socially following the form in which it is thought to be accepted.

- Turner's self-categorization (1987): maintains that people do not exercise as individual beings, but as social beings who extract part of their identity from the environments they belong to. The connection between this theory and the invisibility process is that discriminated groups try to hide their most stereotyped traits, weakening their cultural identity.

- Theory of Communicative Action [59]: according to this theory, every human act is supported by a communicative action in which three types of scenarios are found: (1) the objective world (reality), (2) the social world (norms), and (3) the subjective world (experiences). These three scenarios become obstacles for discriminated groups and connect this theory with the process of invisibility, since these groups do not manage to thematize an aspect of reality (objective world) because they challenge the social world governed by the norm and controlled by the dominant elite.

- Theory of State Formation [60]: It is argued that the State is established through social fractures, resulting from the tension between center/periphery, urban/rural, secular/religious, and industrialemployers/employees, to the point of invisibility of non-dominant groups. 
The non-image, the non-personification, and the absence of any identity mark are one of the stratagems of dehumanization adopted by the social media par excellence. As a counterweight to this invisibility, Muslims have demonstrations, such as the protest held in Barcelona in 2017 'not in our name', showing their express rejection of terrorism.

Social media create 'otherness' by giving more coverage to terrorist acts in Western countries than in Islamic nations, building the reality that Muslims are an internal threat, and making invisible the deaths and terrorist attacks that occur in the very Arab societies where the vast majority profess Islam, who are also victims [61]. Bauman (2006, p. 87) [62] also addressed this problem by stating that the invisibility of these deaths is an "unavoidable side effect of the construction of order".

From the point of view of communication, as a measure to make minorities visible, media education encourages critical thinking and as a measure to detect the underlying contents of ideological messages [63]. People have had a little learning experience about social media and digital competence, making the citizen what Romero-Rodriguez et al., $(2019$, p. 22) [63] considers to be an "analphanaut":

The analphanaut is characterized as an individual who dominates digital competencies, and they are part of their information consumption habits. However, they lack info diets and information filtering capacity in a dual way. Firstly, they receive more content than they can process cognitively, thus emerging the characteristics of informational oversaturation, infoxication, infobesity, and data smog. This situation can be identified by the number of activities they carry out in parallel through multitasking navigation, which has a direct impact on their ability to pay attention to the activities carried out in parallel online vs. offline, but also by the activities they carry out on the fourth screens during their browsing.

Another possible action that could be considered to avoid the Muslim people's symbolic oppression should be clarifying the difference between Arab culture, the Muslim religion, and Islam. Their confusion makes it difficult to see the dehumanization taking place over them. In the specific case of discrimination, the image that the social media have spread and publicized regarding Muslim cultures has been sufficiently negative for a stereotype linked to violence and the absence of ethical and moral values to be in force to this day, and a significant extent worldwide.

\section{Materials and Methods}

\subsection{Sample}

This study examines the images and texts published in Instagram posts under the hashtag \#Stopislam. The sample consists of 474 posts published between 1 January and 31 July 2020, on Instagram, which has been, according to Statista (2020) [12], the social network with the highest increase in users during the quarantine caused by the Covid-19 pandemic. Although this hashtag started to be viral in 2017 , it has continued to be active and reaching more people so far. The number of posts under the hashtag \#StopIslam is 17.3k. However, from 1 January to 31 July 2020, there are 474 posts (effective sample) (Table 1), which will be analyzed.

Table 1. Number of posts per month (sample).

\begin{tabular}{cc}
\hline Month & $f$ \\
\hline January & 51 \\
February & 64 \\
Mach & 41 \\
April & 49 \\
May & 57 \\
June & 105 \\
July & 107 \\
\hline
\end{tabular}


This study analyzes how Instagram is used as a means of oppression to devalue the Muslim collective through the hashtag \#Stopislam. The research questions in this study are: RQ1: How Instagram foment Islamophobic hate? RQ2: How is Instagram used to demonize Muslims? RQ3: Which are the social consequences of demonization and hate speech promotes through the hashtag?

It should be noted that this research is a case study, so the research questions are analyzed through the \#StopIslam hashtag. Besides, as a clarification of Research Question 3 (RQ3), it is important to emphasize that we are studying whether the promotion of the consequences of demonization mentioned by Putri et al., (2020) [23] is observed through the \#StopIslam hashtag, not the effect on society of the analyzed posts.

It must be expressed that one of the difficulties presented in this research has been the language of each of the publications. This problem has been solved thanks to the Instagram tool "see translation" and the use of Google Translate for some images that contained text. This has allowed a complete and comprehensive analysis to develop the conclusions.

\subsection{Instruments}

To carry out this study and answer the questions set out above, empirical research with a mixed methodology is being carried out. Firstly, a qualitative analysis is carried out using as the main instrument of analysis the technique of data collection known as "five walls of Islamophobic hate" (Table 2), validated by Imran Awan, from the University of Birmingham, in the research entitled Islamophobia online inside Facebook's walls of hate ${ }^{1}$ [64] and adapted to the social media Instagram to carry out this research. The adaptation has not required significant modifications, as the primary tool was developed by the Online Hate Centre (2013) for the publication "Islamophobia on the Internet" [65] and adapted to Facebook by Imran Awan. This justifies that the tool can be extrapolated to all the platforms that the network offers, and therefore to Instagram. This analysis tool comprises five codes that comprehensively assess Islamophobia and have been used in other recent research [66].

Table 2. Five walls of Islamophobic hate.

\begin{tabular}{ll}
\hline \multicolumn{1}{c}{ Instagram Walls of Hate } & \multicolumn{1}{c}{ Types of Engagement } \\
\hline \multirow{2}{*}{ Muslims are Terrorist } & Representation of Muslims in social media as aggressive and terrorists. \\
\cline { 2 - 2 } Muslims as Rapists & No difference is made between people who practice Islam and terrorists. \\
\hline Muslim women are a security threat & $\begin{array}{l}\text { Representation of Muslim people as serial rapists and a danger to women. } \\
\text { to national security. }\end{array}$ \\
\hline A war between Muslims & $\begin{array}{l}\text { The promotion of Islamophobia by showing Muslims as war subjects } \\
\text { serve as a tool for the extreme right to promote patriotism. }\end{array}$ \\
\hline Muslims should be deported & $\begin{array}{l}\text { The idea that an invasion is taking place is used to create campaigns } \\
\text { against Islamic law, promoting that they should be expelled because they } \\
\text { put Western identities at risk. }\end{array}$ \\
\hline \multicolumn{1}{c}{ Source: [49]. }
\end{tabular}

To manage and analyze the qualitative data, we have used the qualitative analysis software (QDA) Atlas.ti, which has allowed us to code each publication. This software facilitates the qualitative analysis of unstructured or semi-structured data that helps identify patterns and meanings. Secondly, the IBM-SPSS v. 25 program has been used to perform the statistical analysis of the data obtained during the qualitative study, thus providing a data set in a structured way.

1 Available in: http://doi.org/10.5281/zenodo.58517. 
Lastly, an analysis of the existing theoretical concepts is also carried out by conducting an in-depth exploration of the most relevant databases; in this case, the Web of Science (WoS) and Scopus. The development of this has been structured in two phases:

1. In Scopus, the search criteria "demonization" with the Boolean algorithm AND intersection with "social media" was used. For the search refinement, a selection of emerging documents from 2010-2019 was chosen, from the Social Sciences area, document type "article", and source type "journals". Before the first screening, 79 documents emerged, which, after refinement, became 34 .

2. In the Web of Science (WoS) case, the same search criteria were used, with 83 documents appearing in the first filtering. For the refinement of the search, the period 2010-2019 was selected, only in the thematic area of the communication, document type "article", obtaining 57 documents from this screening. A review of the literature and grounded theory was carried out with which the same epistemological, ontological, and theoretical forms would be correlated. The selection criteria (or screening criteria) for the documentary analysis were the following:

- Thematic connection: 79 documents were analyzed in Scopus and 83 in WoS, refining only those related to the study object. After this screening, 34 documents were selected in Scopus and 57 in WoS.

- The novelty of the contribution: The number of emerging citations in WoS and Scopus, within the period 2010-2019, were considered, emphasizing the most recent ones.

- By the most cited: The most cited works were considered. A total of 91 documents emerge between the two interfaces after the screening, of which only those with more than 20 citations were taken into account.

\section{Results}

In the period analyzed, corresponding to the interval between 1 January and 31 July 2020, the hashtag \#StopIslam presents a total of 474 publications. These represent the definitive sample analyzed and from which the results presented below are extracted. The most frequent Islamophobic behaviors are "A war between Muslims," reaching the highest percentage every month between $55.6 \%$ and $73.5 \%$, and "Muslims are terrorists" with a percentage between $31.4 \%$ and $7.5 \%$ in second place. From the total of the selected sample, a total of 557 pop-up codes are extracted, distributed according to Table 3.

Table 3. Variable frequency results.

\begin{tabular}{llllllll}
\hline \multicolumn{1}{c}{ Variables } & January & February & March & April & May & June & July \\
\hline Muslims are Terrorists & $16.7 \%$ & $7.5 \%$ & $12.2 \%$ & $31.4 \%$ & $16.7 \%$ & $18.3 \%$ & $18.2 \%$ \\
Muslims as Rapists & $1.4 \%$ & $5.0 \%$ & $2 \%$ & $2 \%$ & $16.7 \%$ & $7.6 \%$ & $8.3 \%$ \\
Muslim women are a security threat & $2.8 \%$ & $0 \%$ & $0 \%$ & $3.9 \%$ & $1.7 \%$ & $0 \%$ & $0 \%$ \\
A war between Muslims & $55.6 \%$ & $63.7 \%$ & $73.5 \%$ & $58.8 \%$ & $60 \%$ & $60.3 \%$ & $68.6 \%$ \\
Muslims should be deported & $23.6 \%$ & $23.8 \%$ & $12.2 \%$ & $3.9 \%$ & $5 \%$ & $13.7 \%$ & $5 \%$ \\
\hline
\end{tabular}

The months of June and July are the ones with the highest number of publications (see Table 1). According to the analysis made, this is because, on 25 May, the murder of George Floyd took place. As a result, the number of publications doubled, increasing the gap of other discursive quality, that is, between "us" and "them".

\subsection{A War between Muslims}

The present code represents $62.92 \%$ of the sample, with 351 codes out of 557 . As a consequence, it can be seen that most of the publications are political, promoting patriotism, and positioning Muslims as a threat to European stability. People who practice Islam are stereotyped as monolithic, increasing social polarization, widening the gap between "us" and "them" and spreading and promoting Islam's hatred. 
Most of this nature's publications belong to Dutch accounts supporting the political party Partij voor de Vrijheid (PVV) and Italian users (and sockpuppets) against migratory movements. This code is also associated with some specific social moments, such as, for example, in March, when Ankara (Turkey) decided to open the borders to Europe for refugees. Following this decision, a mobilization against the migrant population's entry was detected under the hashtag \#StopIslam, relating the refugees directly to Islam and positioning them as a threat to European culture.

On the other hand, the months of June and July see the highest number of publications (105 and 107) and encodings (78 and 82). This is due to the social networking movement of \#BlackLivesMatter and its counter-narrative \#WhiteLivesMatter, which associates people of color with Islam's practice (see Figure 2). This association reflects the misinformation and ignorance of the population about Islam's meaning, reflecting the unfamiliarity and impossibility of understanding "others".

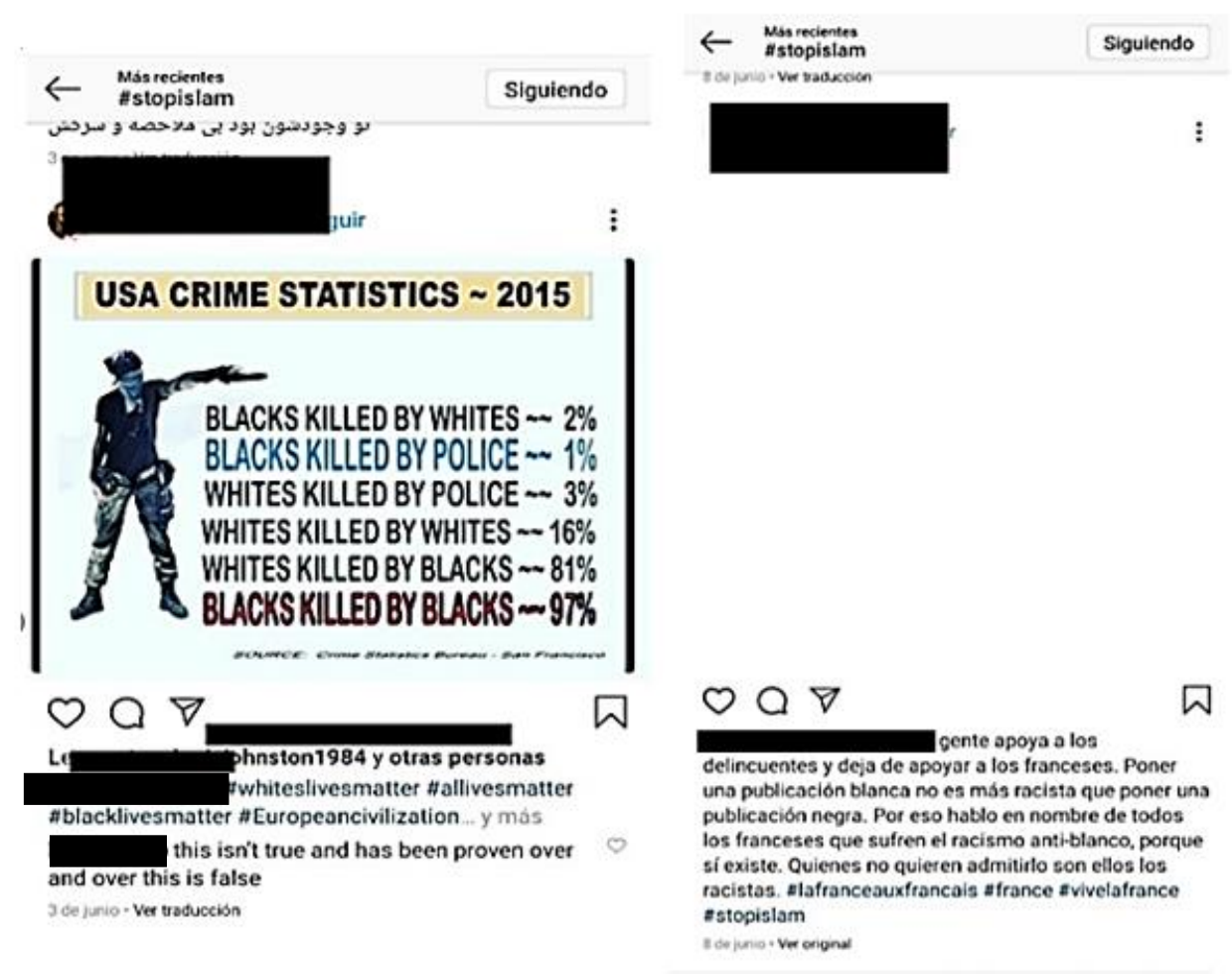

Figure 2. Examples from the category A war between Muslims. Caption: People support criminals and stop supporting the French. Putting a white post is no more racist than putting a black post. That is why I speak on behalf of all French people who suffer from anti-white racism, because it does exist. Those who don't want to admit it are the racists.

After carrying out this first part of the analysis, with the justification of defending European culture, we observe two accounts that are mainly dedicated to publishing unsubstantiated content that incites hatred towards Muslim people. The first is @deutscher.zusammenthalt, which has 8403 followers and defines itself as a media, and the second @waarheidsteller02 with 1616 followers. Both accounts publish memes, fake news, and spam under the analyzed hashtag to fill Instagram with hate messages. After identifying these accounts' type of content, they have been reported to the platform claiming to promote Islamophobia, using an analogy of war. In response to this complaint, Instagram has claimed to have reviewed the accounts and has not detected any incidents. Other accounts reported to have generated hate speech and false news reporting include @stop_islamizacion, @stop.islam, and @_stop.islam (Figure 3). Although Instagram does not detect it as illegal material because it does not promote actions against the law, it does observe discursive attacks on Muslims through the publication of messages that promote false ideas about Islam (e.g., Figure 4). This, according to some authors such as Putri et al., (2020) [23], can be considered as hate speech, so the Instagram policy should 
be reviewed. Poole (2020) [52] also finds this very concerning, because it illustrates how social media platforms' strategies can create conditions that lend themselves not just to the actions but ideological commitments of right-wing populist groups.

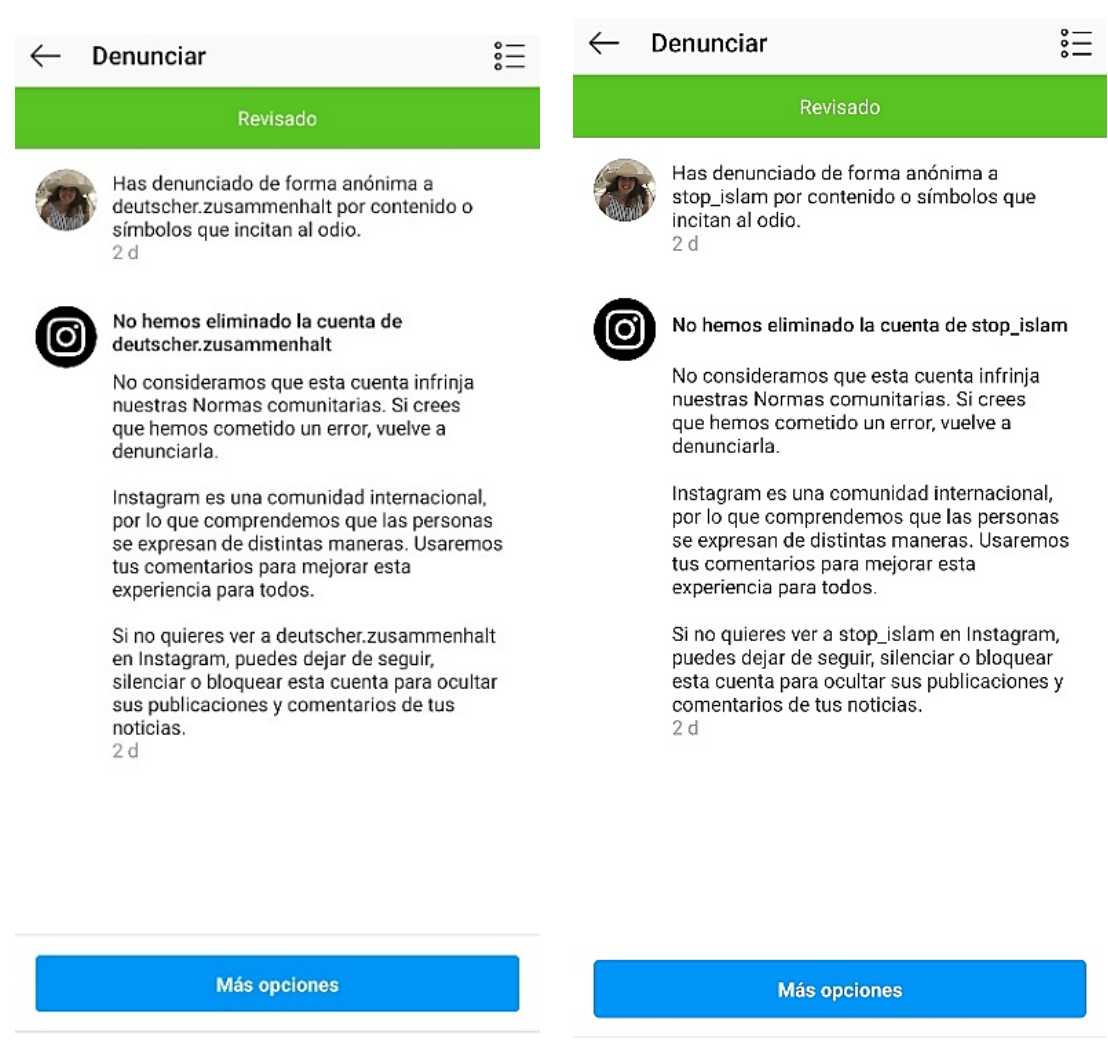

Figure 3. Examples of Instagram's institutional response to Islamophobia complaints. Caption: We do not consider this account to violate our community standards. If you think we have made a mistake, report it again. Instagram is an international community so we understand that people express themselves in different ways. We will use your feedback to improve this experience for everyone. If you do not want to see the content of xxxx you can unfollow, mute or block this account to hide its publications and news comments.

\subsection{Muslims Are Terrorists}

Secondly, $17.28 \%$ of the sample with a total of 96 codifications, publications with the hashtag \#StopIslam that are detected relate religion with terrorism presented to Muslim people as unable to adapt to new realities and to promote in public opinion the idea that people who practice Islam are aggressive and threatening to democratic societies, justifying in this idea discrimination and hatred. The most abundant publications are memes in which Muslim people are demonized and stigmatized and are associated with terrorism through the use of guns, cathanas, and bombs, making reality invisible and stereotyping Islam's practice, laying the foundation for a confrontation through social terror and altering the perception of reality. In contrast, according to the International Observatory of Studies on Terrorism [67], Europe only represents $0.08 \%$ of jihadist activity in the world. This discourse is not associated with any specific date. It is a constant discourse that places Muslims as threats and allies to terrorism (Figure 4). 

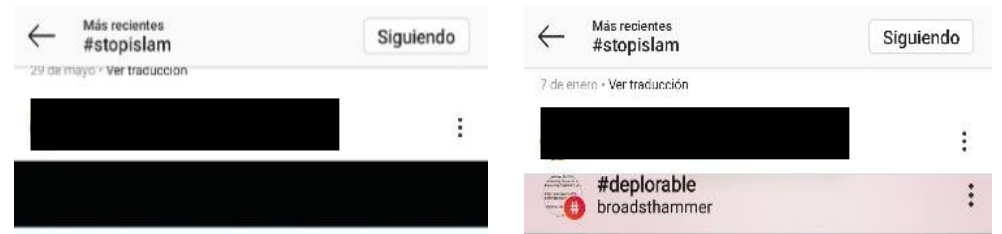

WHY THE DIFFERENCE?
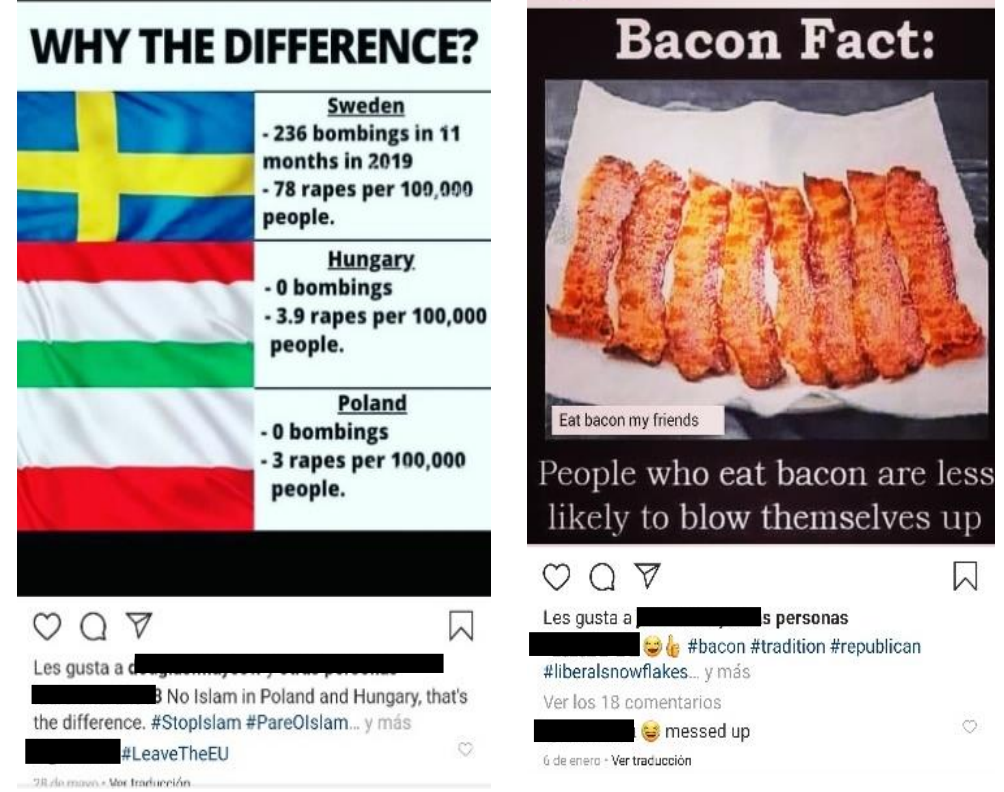

Figure 4. Examples from the category Muslims are terrorist.

\subsection{Muslims Should Be Deported and Muslims as Rapists}

The dissemination of publications with the idea that Muslims invade Europe and should be expelled represents $12.44 \%$ of publications with a total of 70 codes. Messages of this kind help to establish in public opinion the concept that Muslims are different, separate, independent, and do not share values with other cultures. According to the Migration Report (2015) [68], the number of Muslims living is thought to be seven times higher than the actual number in most countries. Therefore, Europe's Islamization and the Muslim invasion are a discourse promoted by certain groups far from reality, since European Muslims represent a minority population.

On the other hand, in fourth place, with 35 codes and with a representation of the sample of $7.60 \%$, some publications emphasize the abuse of Muslims towards girls and women, based on unverified images, false news, and messages of hate with the intention of promoting the idea of \#StopIslam through social networks. It is identified that followers of extreme right-wing political parties create profiles that share this type of disinformation during the specific campaigns, and then they are no longer active. It shows a clear intention to alter the algorithms to manipulate the information and get new followers.

Thus, some accounts are detected under the hashtag \#StopIslam intending to do counter-narrative and fill social networks with positive messages under a negative label, although they are not enough to counteract the gap. Some of these accounts are @Jhditmwh with 259 followers and over 1500 posts and @quran_mylife2 with 56 followers and 52 posts (Figure 5).

\subsection{Muslim Women Are a Security Threat}

Finally, only $1.2 \%$ of the 557 emerging codes belong to the relationship between women and terrorism. This is because most of the posts that have been published under the analyzed hashtag are political and have significant interests in promoting the polarization of societies and the demonization of Muslim people by supporting the Muslim-terrorist binomial. Publications that refer to women are often more related to women's objectification and their dress than to the threat to national security (Figure 6). 

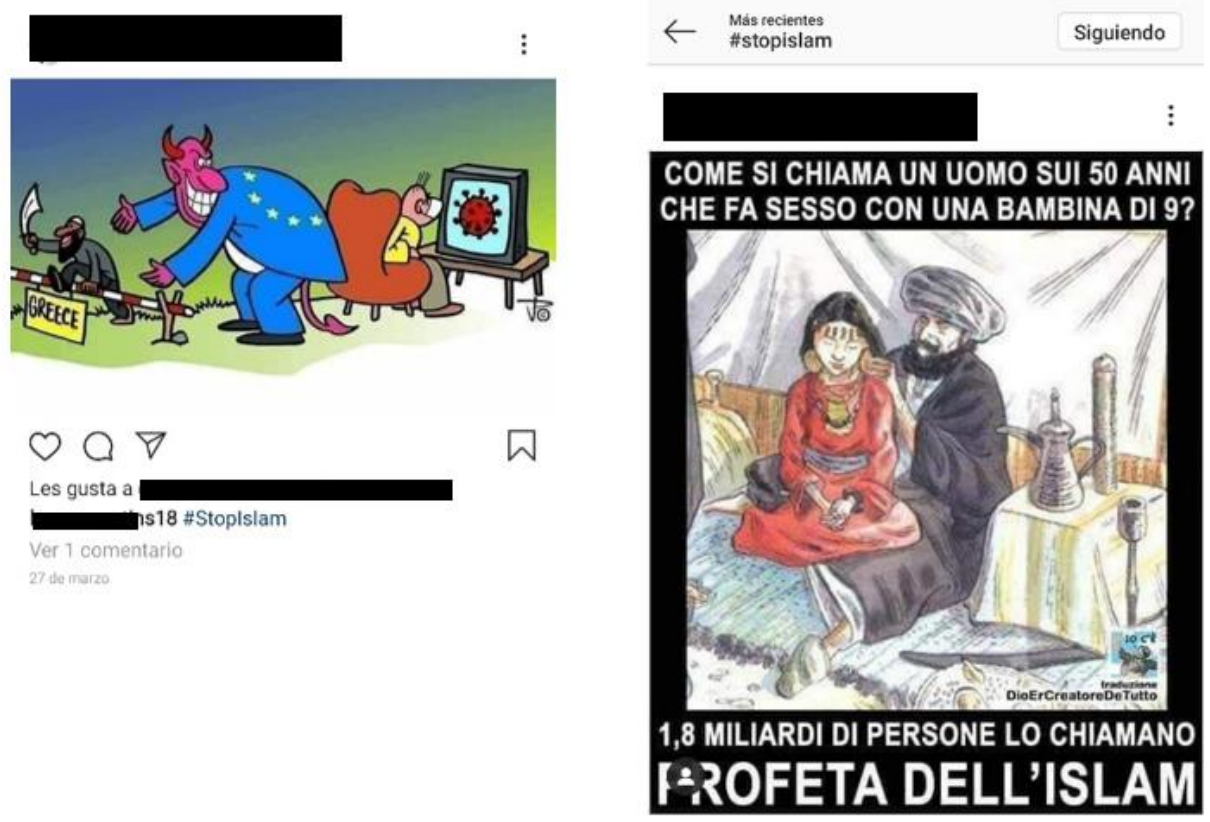

$\circ \bigcirc \nabla$

Les gusta a guesto e' I' \#islam \#stopislam

\#todoscontrapedofilia \#stoppedofilia... y más

Ver los 16 comentarios

$\mathrm{n}$ Ho dato un occhiata alla tua page, non

so, vuoi urlare ancora piủ forte che sei un ritardato,

Figure 5. Examples from the category Muslims should be deported and Muslims as rapists. Caption: What is the name of a man who with 50 years has as a partner a girl of 9 ? 1.8 million people call him the prophet Muhammad.

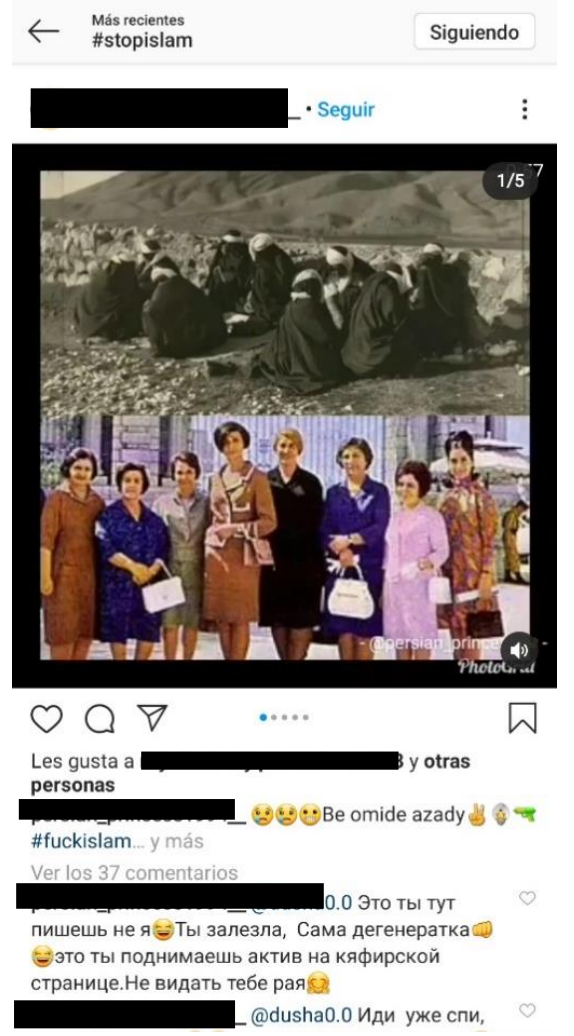

Figure 6. Examples from the category Muslim women are a security threat. 


\section{Discussion and Conclusions}

The process of demonization through the \#StopIslam hashtag is mainly carried out by portraying Muslims as executors of criminal acts, such as in the case of Fitna, a documentary launched in 2008 by Duch MP [69], in addition to showing them as disrespectful people who have difficulties in integrating. However, as one of the limitations of this study, it is noteworthy that the total proportion of demonization on Instagram is unknown, as this analysis is a case study. Although many people may avoid the messages sent with the hashtag due to their cultural level, interest in Islam, or sympathy with Muslims, as can be seen in the case of Fitna mentioned above, in which the authors show how the population turned against this demonizing attitude identifying terrorism with Islam and the people who practice this religion is the most severe Islamophobia [70]. According to a study carried out by Alanazi (2015, p. 588) [70] on the Spanish newspaper El País, 90\% of the sources used to talk about Islam are Western, and only $4 \%$ of the Islamic terms appear in positive contexts. Most references are to Islamic terrorism, Muslim women, conflict, the incompatibility of Islam and democracy, Muslim resentment of the West, and the difficulty of integration [70], as we can also see in this research. In this regard and according to Putri et al., (2020) [23], some of the malpractices that encourage the demonization of Islam are sensational and exaggerated headlines, excessive use of false science, i.e., use of unreasonable statistical figures, misuse of Arabic vocabulary and concepts, disinformation, through the use of few sources and no verification of facts, excessive use of generalizations, a sexist portrayal of Muslims and instrumentalization of Islam, and use of references to Islam as a military ideology.

\subsection{RQ1: How Does Instagram Foment the Islamophobic Hate?}

One of the main conclusions of the present study is the evidence of how the social network Instagram, belonging to Facebook, serves as a platform to promote hate and Islamophobia, allowing the expansion of anti-democratic messages through hashtag \#Stopislam. After reporting different accounts with Islamophobic content (Figure 3), it was found that the community standards policies followed by Instagram consider hate speech as an element or content that does not incite enmity. This behavior allowed by Instagram causes the gap between "us" and "them" to widen, polarizing societies, contributing to certain political parties gaining support and causing social conflict.

Therefore, it can be said that the combination of demonization and social media oppresses non-dominant cultures, limiting their freedom of expression, preventing the satisfaction of the basic needs of these people, and indirectly forcing them to pretend to be. Prejudices and stereotypes about the Arab world continue to expand and spread in the digital environment so that, in recent years, social alarm has increased over the ability of these media to increase and propagate hate speech [71]. The current media ecosystem offers social intercommunication, which has affected how societies are built, social relations, and the concept of "us" and "them".

On the other hand, this analysis detects the internalization of hate speech to such an extent that social platforms like Instagram accept it in their behavior policies. Moreover, a large number of false news, messages full of misinformation, and repulsion towards Muslims are detected under the hashtag \#StopIslam. The main concern about these messages' permissiveness is the indirect support to extremist groups that move their discourse to the offline environment and increase Islamophobia and hate crimes.

Instagram serves as a platform to promote hatred of Islam by those who use the hashtag to post islamophobic messages and stereotyping and denigration of people who practice Islam, as can be seen in the examples given in the results. According to Ruiz et al., (2010, p. 38) [72], "Digital conversations contain anti-democratic, racist, xenophobic and anti-human rights comments, despite the express prohibition to disseminate them". In this sense, the hate mentioned above speeches is formalized through discursive practices, using pragmatic strategies and expressions of hate and threat, which are considered symbolic and discursive violence. Therefore, one of the behaviors that can be observed is that there is symbolic oppression on Instagram, attacking the oppressed invisibly, reproducing a series of categorical denigrations of Islam as a religion, community, and social movement, strengthening the 
relationship between dominant and dominated and dehumanizing Muslim people. This is one of the behaviors found in this platform, demonstrated in the analyzed case.

\subsection{RQ2: How Is Instagram Used to Demonize Muslims?}

The hashtag \#StopIslam promotes racism, Islamophobia, and invisibility through hate speech, agenda-setting, and framing the information. It can be argued that Instagram is a network that uses a group of people interested in demonizing Muslim people and meet under this hashtag. As we have observed in the documentary analysis results referred to ut supra, most of the posts related to Muslims are focused on political issues and terrorism, causing the sensation of threat and, therefore, fomenting hatred towards Muslims. Behind this information hides what we have seen throughout the analysis as 'modern racism', since it is relevant and contrasting news but hides subtle elements against the Muslim collective, which are based on the introduction of public opinion elements that will be accepted by society and will cause their deterioration. Besides, with social media and the algorithms behind them, this hate phenomenon is rising, causing more and more hate crimes in society.

The primary way to demonize Muslim people through this hashtag on Instagram is composed of three pillars, (i) through the political messages of extreme right-wing groups such as PVV, (ii) reinforcing and expanding the Muslim-terrorist binomial, and (iii) inciting fear of being invaded by a culture that does not fit with the European. Although the present study shows that most messages are related to the category a war between Muslims, according to the conclusive results of the Observatory on Islamophobia in the Media [Observatorio de Islamofobia en los Medios] extracted from the research An indisputable reality: Islamophobia in the media (Una realidad incontestable: la Islamophobia en los medios) (2018) [73], 90\% of the news on Islam/Muslims refers to negative aspects, and the issue of terrorism dominates the reporting on Islam: out of 1659 articles examined, 1150 deal with terrorism.

On the other hand, incorrect terminology to describe Islamic aspects is detected, as seen through \#StopIslam in publications about George Floyd. Are all black people Muslim? Finally, it shows how to simplify the context of the Arab world and personify Islam, showing it as if it were one person, delimiting Islam's diversity and respecting each of the followers of this religion [73].

\subsection{RQ3: Which Are the Social Consequences of Demonization and Hate Speech?}

After carrying out this analysis, we could extract as a novelty the reflection that the combination of social media with elements that have serious consequences such as demonization brings with its new consequences and phenomena still to be developed. This is because people abuse this and send offensive comments that could negatively affect the people [23]. Some of these consequences that we can name are changes in relating to the 'other', the emergence of new concepts such as the "mononational" that would be the identification and support of a single nationality, discrediting the rest, and, finally, total deglobalization.

As can be seen, these are consequences that would violate the human rights of people who belong to the minority, so responsible journalism is proposed as a solution to oppression and the promotion of social exclusion, in which people are not presented as categories, and sensationalist headlines are avoided, and more is reported than is misinformed. According to De Pablos, 2011 [74] this would help the information be free of impurities and relate important facts and social issues. Another relevant aspect to stopping this phenomenon is media education, through which the population is helped to identify the messages of hidden hatred and reflect on what is read, and to identify false news. The use of media literacy to prevent the spread of hate and decontextualized ideas in public opinion is fundamental, and a tremendous digital gap is detected that influences the way of understanding the social networks of each one. Therefore, it is proposed to carry out a program of education and communication both in the classroom and at a general level to counteract hate speech damage and teach the current denunciation of hate speech.

For further research, it is proposed to analyze the connection between the hashtags \#StopIslam and \#BlackLivesMatter to better understand African-Americans and Islam's relationship. 
Author Contributions: Conceptualization, S.C. and L.M.R.-R.; methodology, A.C.; formal analysis, S.C., L.M.R.-R. and A.C.; investigation, S.C., L.M.R.-R. and A.C.; resources, S.C.; data curation L.M.R.-R.; writing-original draft preparation, L.M.R.-R.; writing-review and editing, S.C.; supervision, L.M.R.-R. All authors have read and agreed to the published version of the manuscript.

Funding: This study is supported by the R+D+I Project (2019-2021), entitled "Youtubers and Instagrammers: Media competence in emerging prosumers" under code RTI2018-093303-B-I00, financed by the Spanish Ministry of Science, Innovation and Universities and the European Regional Development Fund (ERDF) and the R+D+I project (2020-2022) entitled "Instagramers and youtubers for the transmedia empowerment of the Andalusian citizenry. Media literacy of the instatubers", with code P18-RT-756, financed by the Government of Andalusia, in the 2018 call for tenders (Andalusian Plan for Research, Development and Innovation, 2020) and the European Regional Development Fund (ERDF).

Conflicts of Interest: The authors declare no conflict of interest.

\section{References}

1. De Sousa Santos, B. Constitución y hegemonía. Luchas contra la dominación global. Chasqui 2017, 136, 13-31. [CrossRef]

2. Civila, S.; Romero-Rodríguez, L.M. Análisis comparativo del framing mediático en agencias internacionales de noticias oriente-occidente. Estudio de caso del atentado al aeropuerto de Estambul. Universitas 2018, 29, 135-156. [CrossRef]

3. Téllez Delgado, V. The "AntijihadistPact" and fightingstrategiesagainstthe "violentradicalization": Legal, political and social implications. Rev. Estud. Int. Mediterráneos 2018, 24, 9-30. [CrossRef]

4. González Muñoz, J. Violencia y libertades. Los medios de comunicación y las culturas del medio oriente. Missoes 2017, 1, 154-173.

5. Romero-Rodríguez, L.M.; Aguaded, I.; Gadea, W. De la demonización a la polarización: Un análisis desde el discurso digital del gobierno y la oposición venezolana. Argos 2015, 32, 97-117.

6. Cleland, J. Racism, football fans, and online message boards: How social media has added a new dimension to racist discourse in English football. J. Sport Soc. Issues 2014, 38, 415-431. [CrossRef]

7. Martinez, M. Redes alternativas de comunicación, framing y la construcción del poder político. Revista CCSS 2011, 6, 269-291.

8. Castell, M. Comunicación y Poder; Alianza Editorial: Madrid, Spain, 2009.

9. Fuchs, C. Social media and the public sphere. tripleC Commun. Capital. Crit. 2014, 12, 57-101. [CrossRef]

10. Fuchs, C. Social Media: A Critical Introduction; Sage Publications: London, UK, 2017.

11. Pérez-Escoda, A.; Garcia-Ruiz, R. Instagramers e Youtubers: Uso pedagógico para el desarrollo de la competencia digital. In Competencia Mediática y Digital: Del Acceso al Empoderamiento; Andalusian Collective for Media Education: Huelva, Spain, 2019; pp. 243-253. Available online: https://bit.ly/3d9jihz (accessed on 18 October 2020).

12. U.S. by Their Attendance Status \& Hours Worked per Week. In Statista-The Statistics Portal. 2020. Available online: https://bit.ly/2ZY1AIE (accessed on 10 August 2020).

13. We are Social and Hootsuite. Social Media Trends. 2019. Available online: https://bit.ly/2IhILdK (accessed on 5 October 2020).

14. Levine, M.P.; Murnen, S.K. 'Everybody knows that mass media are/are not [pick one] a cause of eating disorders': A critical review of evidence for a causal link between media, nega-tive body image, and disordered eating in females. J. Soc. Clin. Psychol. 2009, 28, 9-42. [CrossRef]

15. Want, S.C. Meta-analytic moderators of experimental exposure to media portrayals of women on female appearance satisfaction: Social comparisons as automatic processes. Body Image 2009, 6, 257-269. [CrossRef]

16. Tiggemann, M.; Anderberg, I. Social media is not real: The effect of 'Instagram vs reality' images on women's social comparison and body image. New Media Soc. 2020, 22, 2183-2199. [CrossRef]

17. Goffman, E. Estigma. La Identidad Deteriorada; Amorrortu: Madrid, Spain, 1963.

18. Patton, D.U.; Brunton, D.W.; Dixon, A.; Miller, R.J.; Leonard, P.; Hackman, R. Stop and frisk online: Theorizing everyday racism in digital policing in the use of social media for identification of criminal conduct and associations. Soc. Media Soc. 2017, 3. [CrossRef]

19. Romero-Rodríguez, L.M.; Römer-Pieretti, M. Proceso de demonización de la oposición política en los hitos discursivos de Hugo Chávez según la prensa digital. Temas Comun. 2016, 32, 95-124. 
20. Field, S. El Manual del Guionista; Plot Ediciones: Madrid, Spain, 1996.

21. Bourekba, M. Discursos estereotipados sobre los musulmanes en España: De moro a musulmán, de islam a musulmanes. In Una Realidad Incontestable: Islamofobia en los Medios; IEMed i Fundación Al Fanar: Barcelona, Spain, 2018.

22. Bastidas, F.; Torrealba, M. Definición y desarrollo del concepto "proceso de invisibilización" para el análisis social. Una aplicación preliminar a algunos casos de la sociedad venezolana. Espac. Abierto 2014, 23, 515-533.

23. Putri, A.; Sriadhi, S.; Sari, D.; Rahmadani, R.; Hutahaean, H. A comparison of classification algorithms for hate speech detection. IOP Conf. Ser. Mater. Sci. Eng. 2020, 830, 1-7. [CrossRef]

24. Baum, B. The Raise and Fall of the Caucasian Race; New York University Press: New York, NY, USA, 2006.

25. Banton, M.; Harwood, J. The Race Concept; David \& Charles: Newton Abbot, UK, 1975.

26. Campos García, A. Racialización, racialismo y racismo. Un discernimiento necesario. Univ. Habana 2012, 273, 184-198.

27. Moore, R. Racialism and the Law; Libertarian Alliance: London, UK, 1986.

28. Fanón, F. Piel Negra, Máscaras Blancas; Akal: Madrid, Spain, 2010.

29. Grosfoguel, R. Decolonizing post-colonial studies and paradigms of political-economy: Trans modernity, decolonial thinking and global coloniality. J. Peripher. Cult. Prod. Luso Hisp. World 2011, 1, 1-38.

30. Espelt, E.; Javaloy, F. El Racismo Moderno; SOS Racismo: Barcelona, Spain, 1997.

31. McConahay, J. Modern racism, ambivalence, and the modern racism scale. In Prejudice, Discrimination and Racism; Dovidio, J., Gaertner, S., Eds.; Academic Press: Orlando, FL, USA, 1986.

32. Taguieff, P. Faceau Racismo; La Decouverte: Paris, France, 1991.

33. Sears, D.; Kinder, D. The good life," white racism", and the Los Angeles voter. In Proceedings of the Conference of the Western Psychological Association, Los Angeles, CA, USA, 15 April 1970. Available online: http://bit.ly/2IsMdyy (accessed on 4 September 2020).

34. Pettigrew, T. The nature oí modern racism in the United States. Rev. Int. Psychol. Soc. 1989, 2, $291-304$.

35. Borker, M. The New Racism. Conservatism and the Ideology of the Tribe; Junction Books: London, UK, 1981.

36. Castles, S. Here for Good. Western Europe's New Ethnic Minorities; Pluto Press: London, UK, 1984.

37. Martín-Cárdaba, M.A.; Brändle, G. Buscando la inclusión de las minorías en un contexto multicultural. Una revisión teórica del prejuicio y de las estrategias para reducirlo. Rev. Sociol. 2012, 98, 79-102. [CrossRef]

38. Allen, C. Islamophobia: Contested Concept in the Public Space. Ph.D. Thesis, University of Birmingham, Birmingham, UK, 2006.

39. Delafosse, M. L'étatactuel de l'islam dans l'Afrique occidental e française. Rev. Monde Musulmán 1910, 5, 32-53.

40. Council of Europe. Introduction. Questions about the question. Chap. 1. In Islamophobia and Its Consequences on Young People; European Youth Center: Budapest, Hungary, 2004. Available online: http://bit.ly/397kb6x (accessed on 14 April 2020).

41. Luostarinen, H. Finnish Russophobia: The story of an enemy image. J. Peace Res. 1989, 2, 123-137. [CrossRef]

42. Sukidi, M. Max Weber's remarks on Islam. The protestant ethic among Muslim puritans. Islam Christ. Muslim Relat. 2006, 2, 195-205. [CrossRef]

43. Saliba, G. Islamic Science and the Making of the European Renaisance; MIT Press: Boston, MA, USA, 1997.

44. Graham, M. How Islam Created the Modern World; Amana Publications: Beltsville, UK, 2006.

45. Conway, G. Islamophobia: A Challenge for Us All; Runnymede Trust: London, UK, 1997.

46. Pew Global Attitudes Project. Negative Views of Minorities Refugees Common in EU. 2006. Available online: https://pewrsr.ch/39vLJUo (accessed on 20 February 2020).

47. Rico, A. Islamofobia. Nosotros, los Otros y el Miedo; Icaria: Barcelona, Spain, 2015.

48. Geisser, V. La Nouvelleislamophobie; La Découverte: Paris, France, 2003.

49. Vakilm, A. Is the Islam in Islamophobia the same as the Islam in anti-Islam; or, when is it Islamophobia time? e-cadernos CES 2009, 3, 74-85. [CrossRef]

50. Allen, C. Anti-social networking: Findings from a pilot study on opposing Dudley mosque using Facebook groups as both site and method for research. Sage Open 2014, 4. [CrossRef]

51. Ramírez, Á. La construcción del problema musulmán: Radicalización, islam y pobreza. Viento Sur 2016, 144, 21-30.

52. Poole, E.; Giraud, E.H.; De Quincey, E. Tactical interventions in online hate speech: The case of \#stopIslam. New Media Soc. 2020, 22, 1-28. [CrossRef] 
53. Said, E. Orientalismo; Libertarias: Madrid, Spain, 1990.

54. Sahagun, F. Contra la islamofobia más y mejor información. In Una Realidad Incontestable: Islamofobia en los Medios; IEMed i Fundación Al Fanar: Barcelona, Spain, 2018; Available online: http://bit.ly/2VT37OH (accessed on 17 June 2020).

55. Horsti, K. Digital Islamophobia: The Swedish woman as a figure of pure and dangerous whiteness. New Media Soc. 2017, 19, 1440-1457. [CrossRef]

56. Törnberg, A.; Törnberg, P. Combining CDA and topicmodeling: Analyzing discursive connections between Islamophobia and anti-feminismonan online fórum. Discourse Soc. 2016, 27, 401-422. [CrossRef]

57. Vidgen, B.; Yasseri, T. Detecting weak and strong Islamophobic hate speech on social media. J. Inf. Technol. Politics 2020, 17, 66-78. [CrossRef]

58. Ortiz, F. Contrapunteo Cubano del Tabaco y el Azúcar; Fundación Biblioteca Ayacucho: Caracas, Venezuela, 1987.

59. Habermas, J. Teoría de la Acción Comunicativa. Complementos y Estudios Previos; Cátedra: Madrid, Spain, 1989.

60. Rokkan, S. Cleavage structures, party systems and voter alignments: An introduction. In Party Systems and Voter Alignments; Free Press: New York, NY, USA, 1967.

61. Daroqui, A. Muertes Silenciadas: La Eliminación de los "Delincuentes": Una Mirada Sobre las Prácticas y los Discursos de los Medios de Comunicación, la Policía y la Justicia; Centro Cultural de la Cooperación: Buenos Aires, Argentina, 2009.

62. Bauman, Z. Vida Líquida; Paidós: Barcelona, Spain, 2006.

63. Romero-Rodríguez, L.M.; Chaves-Montero, A.; Torres-Toukoumidis, A. Neopopulismo, poder y control social: Las competencias mediáticas en ideología y valores como defensa de la ciudadanía. Lumina 2018, 12, 40-54. [CrossRef]

64. Awan, I. Islamophobia on social media: A qualitative analysis of the Facebook's walls of hate. Int. J. Cyber Criminol. 2016, 10, 1-20. [CrossRef]

65. Online Hate Prevention Centre. Islamophobia on the Internet: The Growth of Online Hate Targeting Muslims. 2013. Available online: http://ohpi.org.au/islamophobia-on-the-internet-the-growth-of-onlinehate-targetingmuslims/ (accessed on 25 May 2020).

66. Curci Walles, A. How Facebook Comments Reflect Certain Characteristics Of Islamophobia: A Critical Discourse Analysis. Ph.D. Thesis, Uppsala University, Uppsala, Sweden, 2019.

67. International Observatory of Studies on Terrorism. Semi-Annual Report on Jihadist Activity. 2020. Available online: https://bit.ly/3hSOqCP (accessed on 27 July 2020).

68. United Nacion. International Migration Report; UN: New York, NY, USA, 2015. Available online: https: //bit.ly/2FHo0qM (accessed on 27 July 2020).

69. Mihelj, S.; Van Zoonen, L.; Vis, F. Cosmopolitan communication online: YouTube responses to the anti-Islam film Fitna1. Br. J. Sociol. 2011, 62, 614-632. [CrossRef] [PubMed]

70. Alanazi, A. Los Términos Árabes e Islámicos en la Prensa Española: Compresión, Traducción y Uso. El Caso del Diario el País. Ph.D. Thesis, University of Málaga, Málaga, Spain, 2015.

71. Miró, F. Taxonomy of violent communication and the discourse of hate on the Internet. IDP Rev. Internet Derecho Politica 2016, 22, 93-118. [CrossRef]

72. Ruiz, C.; Pere, M.; Micó, J.; Díaz-Noci, J.; David, D. Conversation 2.0. and democracy. An analysis of reader's comments in Catalan online newspapers. Comun. Soc. 2010, 2, 7-39.

73. Observatory on Islamophobia in the Media. An Indisputable Reality: Islamophobia in the Media. 2018. Available online: https://bit.ly/3hT32Ca (accessed on 12 October 2020).

74. De Pablos Coello, J.M. Periodismo es preguntar. Glob. Media J. México 2011, 10, 74-75.

Publisher's Note: MDPI stays neutral with regard to jurisdictional claims in published maps and institutional affiliations.

(C) 2020 by the authors. Licensee MDPI, Basel, Switzerland. This article is an open access article distributed under the terms and conditions of the Creative Commons Attribution (CC BY) license (http://creativecommons.org/licenses/by/4.0/). 